Jurnal Akuntansi \& Perpajakan, Volume 3, No. 1, Juli 2021

\title{
LAPORAN REKAPITULASI BULANAN \\ KOPERASI SIMPAN PINJAM JASA INDAH MAKMUR \\ UNIT KUDUS

\author{
Ferlina Ardiyan
} \\ Jurusan Administrasi Bisnis Sektor Publik, Politeknik STIA LAN Bandung
}

\begin{abstract}
Tujuan dari penelitian ini adalah untuk mengetahui laporan perkembangan selama sebulan di KSP Jasa Indah Makmur apakah mengalami perubahan keuntungan atau penurunan keuntungan. Metode yang digunakan dalam penelitian ini adalah metode kualitatif, sedangkan populasi dalam penelitian ini adalah seluruh karyawan Koperasi Jasa Indah Makmur yang berjumlah 17 orang dan sampel yang penulis tentukan berjumlah 4 orang. Jenis dan sumber data yang digunakan meliputi data kuantitatif dan data kualitatif serta sumber data yang digunakan adalah data primer dengan teknik pengumpulan data terdiri dari observasi, wawancara dan dokumentasi. Teknik analisis yang digunakan adalah data kualitatif dalam bentuk keterangan dan pembahasan teoritis yang bertujuan menganalisa hal-hal yang dapat dianalisa bukan dengan angka-angka tetapi dengan teori-teori yang dibuktikan dengan kenyataan yang terjadi dikantor KSP Jasa Indah Makmur. Hasil penelitian menunjukkan dalam bulan Mei ini KSP Jasa Indah Makmur mengalami peningkatan keuntungan dan peningkatan anggota yang akan menjadi anggota di Koperasi Jasa Indah Makmur Kudus.
\end{abstract}

Kata kunci: Rekapitulasi Bulanan, Koperasi Simpan Pinjam, Kualitatif 
Jurnal Akuntansi \& Perpajakan, Volume 3, No. 1, Juli 2021

\section{PENDAHULUAN}

Perkembangan koperasi yang ada didunia bermula pada abad ke-20 yang pada umumnya merupakan hasil dari usaha yang tidak spontan dan tidak dilakukan oleh orang-orang yang sangat kaya. Koperasi pertama kali diperkenalkan oleh seorang berkebangsaan Skotlandia, yang bernama Robert Owen (1771-1858). Setelah koperasi berkembang dan diterapkan di beberapa Negara-negara eropa. Koperasi pun mulai masuk dan berkembang di Indonesia. Koperasi tumbuh dari kalangan rakyat, ketika penderitaan dalam lapangan ekonomi dan sosial yang ditimbulkan oleh system kapitalisme semakin memuncak. Beberapa orang yang penghidupannya sederhana dengan kemampuan ekonomi terbatas, terdorong oleh penderitaan dan beban ekonomi yang sama, secara spontan mempersatukan diri untuk menolong dirinya sendiri dan manusia sesamanya. Dalam keadaan hidup demikian, pihak kolonial terus-menerus mengintimidasi penduduk pribumi sehingga kondisi sebagian besar rakyat sangat memprihatinkan. Di samping itu para rentenir, pengijon dan lintah darat turut pula memperkeruh suasana. Mereka berlomba mencari keuntungan yang besar dan para petani yang sedang menghadapi kesulitan hidup, sehingga tidak jarang terpaksa melepaskan tanah miliknya sehubungan dengan ketidakmampuan mereka mengembalikan hutang-hutangnya yang membengkak akibat sistem bunga berbunga yang diterapkan pengijon dan tidak terlepas pada saat itu dikenal dengan adanya sistem kolonialisme yang telah banyak menyengsarakan kaum buruh pada umumnya dan membuat mereka harus berpikir bagaimana caranya mereka untuk dapat keluar dari permasalahan yang telah lama mereka rasanya dan hadirlah suatu koperasi yang bertujuan untuk menolong kaum buruh yang pada awal itu dikenal dengan koperasi Pra industri. Di Indonesia koperasi mulai diperkenalkan oleh Patih R.Aria Wiria Atmaja pada tahun 1896, dengan melihat banyaknya para pegawai negeri yang tersiksa dan menderita akibat bunga yang terlalu tinggi dari rentenir yang memberikan pinjaman uang. Melihat penderitaan tersebut Patih R.Aria Wiria Atmaja lalu mendirikan Bank untuk para pegawai negeri, beliau mengadopsi system serupa dengan yang ada di jerman yakni mendirikan koperasi kredit. Beliau berniat membantu orang-orang agar tidak lagi berurusan dengan renternir yang pasti akan memberikan bunga yang tinggi. Seorang asisten residen Belanda bernama De Wolffvan Westerrode, merespon tindakan Patih R.Aria Wiria, sewaktu mengunjungi Jerman De Wolffvan Westerrode menganjurkan akan mengubah Bank Pertolongan Tabungan yang sudah ada menjadi Bank Pertolongan, Tabungan dan Pertanian. Setelah itu koperasi mulai cepat berkembang di Indonesia, hal ini 
Jurnal Akuntansi \& Perpajakan, Volume 3, No. 1, Juli 2021

juga didorong sifat orang-orang Indonesia yang cenderung bergotong royong dan kekeluargaan sesuai dengan prinsip koperasi. Bahkan untuk mengansitipasi perkembangan ekonomi yang berkembang pesat pemerintahan Hindia-Belanda pada saat itu mengeluarkan peraturan perundangan tentang perkoperasian.

Pertama, diterbitkan Peraturan Perkumpulan Koperasi No. 43, Tahun 1915, lalu pada tahun 1927 dikeluarkan pula Peraturan No. 91, Tahun 1927, yang mengatur Perkumpulan-Perkumpulan Koperasi bagi golongan Bumiputra. Pada tahun 1933, Pemerintah Hindia-Belanda menetapkan Peraturan Umum Perkumpulan-Perkumpulan Koperasi No. 21, Tahun 1933. Peraturan tahun 1933 itu, hanya diberlakukan bagi golongan yang tunduk kepada tatanan hukum Barat, sedangkan Peraturan tahun 1927, berlaku bagi golongan Bumiputra. Setelah pemerintahan Hindia-Belanda menunjukkan sikap diskriminasi dalam peraturan yang dibuatnya. Pada tahun 1908 Dr. Sutomo yang merupakan pendiri dari Boedi Utomo memberikan peran nya bagi gerakan koperasi untuk memperbaiki kondisi kehidupan rakyat. Serikat Dagang Islam (SDI) 1927, Dibentuk bertujuan untuk memperjuangkan kedudukan ekonomi pengusaha-pengusaha pribumi. Kemudian pada tahun 1929, berdiri Partai Nasional Indonesia yang memperjuangkan untuk menyebarluaskan semangat koperasi. Setelah Jepang berhasil menguasai sebagian besar daerah Asia, termasuk Indonesia, system pemerintahan pun berpindah tangan dari pemerintahan Hindia-Belanda ke pemerintahan Jepang. Jepang lalu mendirikan koperasi Kumiyai, namun hal ini hanya dimanfaatkan Jepang untuk mengeruk keuntungan, dan menyengsarakan rakyat Indonesia. Setelah Indonesia merdeka, pada tanggal 12 juli 1947, pergerakan koperasi di Indonesia mengadakan Kongres Koperasi yang pertama di Tasikmalaya. Hari ini kemudian ditetapkan sebagai Hari Koperasi Indonesia.Sekaligus membentuk Sentral Organisasi Koperasi Rakyat Indonesia (SOKRI) yang berkedudukan di Tasikmalaya. Lalu kita mengenal Moh. Hatta sebagai bapak koperasi. Beliau mengusulkan didirikannya 3 macam koperasi :

Pertama, adalah koperasi konsumsi yang terutama melayani kebutuhan kaum buruh dan pegawai. Kedua, adalah koperasi produksi yang merupakan wadah kaum petani (termasuk peternak atau nelayan). Ketiga, adalah koperasi kredit yang melayani pedagang kecil dan pengusaha kecil guna memenuhi kebutuhan modal. Bung Hatta mengatakan bahwa tujuan koperasi yang sebenarnya bukan mencari laba atau keuntungan, namun bertujuan untuk memenuhi kebutuhan bersama anggota koperasi. Koperasi Jasa Indah Makmur merupakan salah satu koperasi primer yang bergerak dibidang usaha simpan pinjam. Pada 
Jurnal Akuntansi \& Perpajakan, Volume 3, No. 1, Juli 2021

Koperasi Jasa Indah Makmur anggotanya juga lebih cenderung untuk melakukan kredit dalam jangka yang pendek. Dalam aturan kantor, dalam 3 bulan anggota harus dapat melunasi pinjaman yang dipinjamnya selama ini. Setelah itu bunga dilakukan berjalan. Hal ini yang digunakan Koperasi Jasa Indah Makmur menggunakan Laporan Rekapitulasi Bulanan.

Laporan Rekapitulasi Bulanan adalah Laporan yang digunakan KSP Jasa Indah Makmur untuk melihat perkembangan yang terjadi di lapangan dan kas yang dikeluarkan selama sebulan. Laporan ini digunakan pimpinan untuk menjadi pedoman bagaimana dapat mengatur karyawan yang ada dilapangan dan mengatur pengelolaan kas setiap bulannya. Kuantitas yang dapat dihitung berkembangnya kantor tersebut dapat dilihat dari :

1) Persentase target

2) Penghitungkan kasbon yang dikeluarkan kantor

3) Storting/Angsuran yang diangsur anggota nasabah

4) Drop/Pinjaman yang dikeluarkan kantor

5) Jumlah tunai yang dihitung setiap harinya

Rekapitulasi bulanan ini ditandangani pimpinan pada akhir bulan dan disetorkan pimpinan unit pusat yang ada di Yogyakarta. Hal ini dilakukan supaya adanya keterbukaan laporan antara unit Kudus dan Unit Koperasi Pusat agar tidak terjadi ketimpangan. Koperasi Jasa Indah Makmur selalu mengutamakan akuntabel, transparan pada laporan yang dibuatnya. Dengan dilakukannya hal ini akan membuat kepercayaan antar pimpinan dan karyawan yang ada di KSP Jasa Indah Makmur agar tidak terjadi kesalahpahaman. Adapun Rekapitulasi Bulanan Koperasi Jasa Indah Makmur pada bulan Mei 2021 dapat dilihat sebagai berikut:

\begin{tabular}{|l|l|l|l|l|l|l|}
\hline $\begin{array}{l}\mathrm{N} \\
\mathrm{o}\end{array}$ & $\begin{array}{l}\text { Kasb } \\
\text { on }\end{array}$ & $\begin{array}{l}\text { Storti } \\
\text { ng }\end{array}$ & $\begin{array}{l}\text { Juml } \\
\text { ah } \\
\text { Debe } \\
\mathrm{t}\end{array}$ & Drop & $\begin{array}{l}\text { Juml } \\
\text { ah } \\
\text { kredit }\end{array}$ & Tunai \\
\hline 1 & 2.91 & 30.05 & 34.07 & 22.35 & 22.60 & 11.47 \\
& 0.00 & 2.000 & 9.500 & 0.000 & 0.000 & 9.500 \\
& 0 & & & & & \\
\hline 2 & 4.71 & 18.92 & 24.43 & 15.90 & 16.18 & 8.251 \\
& 8.00 & 3.000 & 6.000 & 0.000 & 5.000 &. \\
& 0 & & & & & 000 \\
\hline 3 & 2.42 & 21.31 & 24.62 & 17.80 & 18.05 & 6.570 \\
& 0.00 & 0.000 & 0.000 & 0.000 & 0.000 &. \\
& 0 & & & & & 000 \\
\hline 4 & 2.47 & 19.69 & 22.80 & 12.80 & 13.45 & 9.351 \\
& 0.00 & 1.000 & 1.000 & 0.000 & 0.000 &. \\
& 0 & & & & & 000 \\
\hline
\end{tabular}

Pada tabel di atas jumlah kasbon menjadi Rp. 12.518.000, jumlah storting Rp. 89.976.000, Sehingga jumlah debet menjadi Rp. 102.494.000, Jumlah Drop Rp.68.850.000, sehingga jumlah kredit Rp. 70.285.000, dan Tunai Rp. 35.651.500. Hal ini berarti kasbon terbanyak dikeluarkan oleh Resort 2. Storting tertinggi di Resort 1. Oleh Karena itu, jumlah debet tertinggi berada di Resort 1 yang mengakibatkan drop tertinggi ada di Resort 1 dan Drop terendah berada di 
Jurnal Akuntansi \& Perpajakan, Volume 3, No. 1, Juli 2021

Resort 4. Sehingga jumlah debet yang pertama ada Resort 1, yang kedua ada Resort 3, yang ketiga ada Resort 2 dan yang terakhir ada pada Resort 4. Tunai yang dihasilkan juga tertinggi berada di Resort 1. Dari tabel tersebut dapat disimpulkan Resort 1 mengalami meningkatan pada kondisi lapangannya.

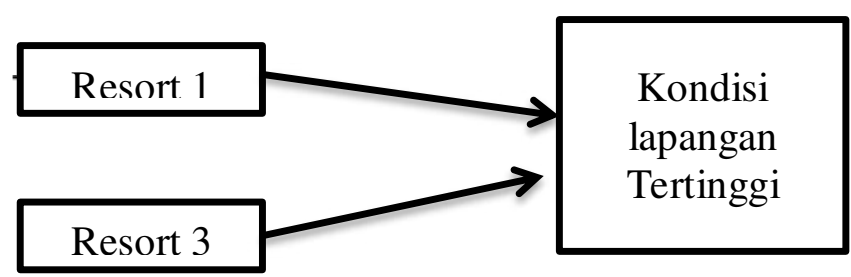

Gambar 1

Permasalahan pada Koperasi Jasa Indah Makmur ini terjadi pada Resort 4 yang memiliki Resort terendah dari yang lainnya karena Storting/Angsuran yang diangsur nasabah jumlah nya lebih sedikit dari Resort lainnya. Hal ini menjadikan catatan Pimpinan untuk lebih mengontrol kondisi lapangan lagi untuk Resort 4.

\section{RUMUSAN MASALAH}

1. Bagaimana perkembangan koperasi di Indonesia?

2. Bagaimana Kuantitas yang dapat dihitung berkembangnya kantor KSP Jasa Indah Makmur tersebut?

3. Bagaimana perkembangan kondisi lapangan pada Koperasi Jasa Indah Makmur Kudus?

4. Berapa saja pemasukan kondisi lapangan setiap per-resort?

5. Bagaimana cara mengatasi penurunan target yang ada di kantor KSP Jasa Indah Makmur?

\section{Batasan Masalah}

Dalam pelaksanaan penelitian yang penulis lakukan, batasan masalah yang dialami adalah kondisi lapangan yang ada apakah dimaksimalkan oleh karyawan yang berada di lapangan atau tidak. Karena pimpinan tidak selalu ada kantor unit Kudus ini.

\section{Tujuan Penelitian}

Berdasarkan rumusan masalah yang telah dikumpulkan, maka tujuan penelitian ini untuk :

1. Mengetahui bagaimana perkembangan koperasi di Indonesia.

2. Mengetahui bagaimana Kuantitas yang dapat dihitung berkembangnya kantor KSP Jasa Indah Makmur tersebut.

3. Mengetahui bagaimana perkembangan kondisi lapangan pada Koperasi Jasa Indah Makmur Kudus.

4. Mengetahui berapa saja pemasukan kondisi lapangan setiap per-resort.

5. Mengetahui bagaimana cara mengatasi penurunan target yang ada di kantor KSP Jasa Indah Makmur.

\section{Manfaat Penelitian}

Manfaat atas penelitian ini mempunyai beberapa aspek antara lain

1. Aspek Akademis

Merupakan suatu kesempatan yang baik untuk mengaplikasikan ilmu yang telah diperoleh di bangku kuliah ke dalam praktek yang sesungguhnya khususnya dalam ilmu Akuntansi Keuangan.

2. Aspek Pengembangan Ilmu

Pengetahuan Hasil penelitian dan analisa ini diharapkan dapat memberikan suatu pandangan teoritis dalam hal Laporan Rekapitulasi Bulanan, juga diharapkan dapat membantu pihak lain dalam mengimplementasikan perkembangan kondisi lapangan pada KSP JASA INDAH MAKMUR. 
Jurnal Akuntansi \& Perpajakan, Volume 3, No. 1, Juli 2021

2. Aspek Praktis

Hasil penelitian ini diharapkan dapat memberikan saran perbaikan sehingga dapat digunakan sebagai bahan evaluasi pada sistem Laporan Rekapitulasi Bulanan di KSP Jasa Indah Makmur.

\section{TINJAUAN PUSTAKA}

\section{Pengertian Laporan Rekapitulasi Bulanan}

Laporan Rekapitulasi Bulanan adalah

Laporan yang dibuat karyawan rekap untuk mengetahui perkembangan kondisi lapangan yang ada di KSP Jasa Indah Makmur untuk meningkatkan target yang disediakan oleh kantor pusat.

Menurut Mintorogo dan Sedarmayanti (1992: 41) Rekapitulasi adalah suatu kegiatan meringkaskan data sehingga menjadi lebih berguna bentuk, susunan, sifat atau isinya dengan bantuan tenaga tangan atau bantuan suatu peralatan dan mengikuti rangkaian langkah, rumus, atau pola tertentu.

Dalam Kamus Besar Bahasa Indonesia (1996 : 828) "Rekapitulasi adalah ringkasan isi atau ikhtisar pada akhir laporan atau akhir hitungan."

Tujuan manfaat pembuatan rekapitulasi bulanan yang paling utama adalah memudahkan pegawai keuangan atau akuntan dalam memposting setiap jurnal ke dalam buku besar pada waktu tertentu. Yang paling umum biasanya adalah pada saat akhir bulan atau sekitar tanggal $25-31$ setiap bulan.
Laporan Rekapitulasi sangat penting bagi seorang pimpinan karena merupakan salah satu alat untuk melaksanakan kegiatankegiatan dalam perencanaaan, pengendalian, pengawasan dan pengambilan keputusan.

Rekapitulasi dilakukan dengan cara merangkum saldo-saldo yang terdapat dalam jurnal khusus ke dalam kolom debet dan kolom kredit. Berdasarkan saldo yang berada dalam kolom debet dan kredit pada rekapitulasi maka sanggup dilihat apakah terjadi keseimbangan atau tidak. Saldo-saldo yang terdapat pada rekapitulasi merupakan saldo yang berasal dari jurnal khusus yang dipindahkan ke dalam kolom debit atau kredit pada rekapitulasi.

\section{Fungsi Laporan Rekapitulasi}

1. Pertanggungjawaban dan pengawasan Laporan rekapitulasi merupakan suatu pertanggungjawaban dari seorang pejabat pimpinan atau petugas kepada atasannya sesuai dengan fungsi dan tugas yang dibebankan kepadanya. Dari laporan itu, pihak atasan akan meneliti tentang pelaksanaan fungsi dan tugas oleh pejabat pimpinan yang bersangkutan.

2. Penyampaian informasi

Bagi pimpinan yang menerima, laporan rekapitulasi merupakan salah satu sumber informasi yang diperlukan dalam melaksanakan fungsi dan tugastugasnya di kantor KSP Jasa Indah Makmur.

3. Bahan pengambilan keputusan 
Jurnal Akuntansi \& Perpajakan, Volume 3, No. 1, Juli 2021

Dalam melaksanakan manajemen, pimpinan harus selalu mengambil keputusan yang diperlukan setiap waktu. Untuk keperluan pengambilan keputusan oleh pimpinan itu, dibutuhkan data atau informasi yang berhubungan dengan keputusan yang diambil.

4. Membina kerja sama

Laporan rekapitulasi dapat dijadikan sebagai salah satu alat untuk membina kerja sama, saling pengertian, dan koordinasi yang setepat-tepatnya antara atasan dan bawahan.

5. Pengembangan

Laporan rekapitulasi merupakan salah satu bentuk atau alat untuk memperluas ide dan tukar-menukar pengalaman antar karyawan yang ada di kantor KSP Jasa Indah Makmur Kudus.

\section{Jenis- Jenis Pinjaman di KSP Jasa Indah Makmur}

1. Berdasarkan Pembayaran

Jenis ini dibagi atas dua yakni pelunasan sekaligus (single payment) dan cicilan (installment). Utang dengan pelunasan sekaligus biasanya dipilih jika masih dalam jumlah yang kecil. Jika pinjamannya cukup besar maka kerap diambil dengan pembayaran cicilan.

2. Berdasarkan Jaminan

Pinjaman berdasarkan jaminan dibagi atas dua yang antara lain utang dengan jaminan agunan (secured loan) dan utang tanpa jaminan agunan (unsecured loan).

3. Berdasarkan Bunga Utang

Untuk jenis ini dibagi atas tiga macam yaitu utang variable rate (effective rate), bunga fixed rate (flat rate) dan bunga anuitas.

4. Berdasarkan Jatuh Tempo

Ada dua jenis utang berdasarkan jatuh tempo yang dibagi menjadi utang jangka pendek (shot term loan) dan utang jangka panjang (long term loan). Utang jangka pendek biasanya memiliki jatuh tempo kurang dari 1 tahun sementara utang jangka panjang memiliki waktu jatuh tempo lebih dari 1 tahun.

Hal-Hal yang Harus Diketahui Nasabah Koperasi Simpan Pinjam

Ada banyak peraturan yang

harus dipatuhi oleh nasabah koperasi simpan pinjam. Koperasi simpan pinjam saat ini mulai banyak digandrungi oleh masyarakat karena mampu untuk memberikan bantuan keungan dengan cepat dan langsung cair dalam beberapa menit. Tentunya hal tersebut juga akan membantu sekali dalam menstabilkan kondisi financial yang dimiliki saat ini agar bisa berjalan dengan lancar. Selanjutnya, nasabah koperasi simpan pinjam juga harus memiliki barang jaminan yang diberikan kepada pihak koperasi terkait dengan sejumlah uang yang nantinya akan bisa mereka dapatkan. Semakin besar jumlah jaminan yang nanti diberikan maka semakin besar pula jumlah uang yang akan bisa didapatkan oleh nasabah. Hal ini tentunya juga akan dapat memberikan manfaat bagi kesejahteraan banyak orang.

Kemudian, nasabah koperasi simpan pinjam juga harus mengetahui berapa kisaran bunga yang harus mereka kembalikan setiap bulannya 
Jurnal Akuntansi \& Perpajakan, Volume 3, No. 1, Juli 2021

apabila telat dalam melunasi pinjaman tersebut. Namun biasanya bunga yang diberikan juga tidak banyak. Semua bergantung pada syarat dan ketentuan yang telah disetujui oleh nasabah dan juga pemilik koperasi tersebut. Dengan adanya peraturan yang mengikat ini maka asas kekeluargaan yang ada dalam koperasi tersebut akan bisa berjalan dengan baik dan teratur sesuai dengan yang ada dalam undang-undang. Di Indonesia ini ada undang-undang yang mengatur kegiatan koperasi sehingga apabila ada masalah di kemudian hari maka akan bisa diselesaikan dengan jalur hukum.

\section{Bunga Koperasi Simpan Pinjam}

\section{Bunga menurun (RC)}

1Penghitungan bunga menurun atau $\mathrm{RC}$ dipengaruhi oleh total pada sisa pinjaman pokok. Jadi, semakin kecil nilai pinjaman yang belum terbayar, semakin kecil juga bunganya. Berikut ini contoh penghitungan bunga menurun.

- Pinjaman pokok: Rp1 juta.

- Suku bunga: $1 \%$.

Penghitungan Bunga Menurun

(Sisa Pinjaman Pokok $\times$ Suku Bunga)/30) $\times$ Jumlah Hari

$\begin{array}{llll}\text { Tanggal } & \begin{array}{lll}\text { Sisa Pinjaman } \\ \text { Pokok }\end{array} & \begin{array}{l}\text { Jumlah } \\ \text { Hari }\end{array} & \begin{array}{l}\text { Angsuran } \\ \text { Bunga }\end{array} \\ \text { 01 Sep } & \text { Rp1 juta } & 18 & \text { Rp6 ribu } \\ 19 \text { Sep } & \text { Rp500 ribu } & 6 & \text { Rp1 ribu } \\ 25 \text { Sep } & \text { Rp300 ribu } & 5 & \text { Rp500 } \\ 30 \text { Sep } & \text { Rp 0 } & 0 & 0 \\ \text { Total Bunga Dibayarkan } & \mathbf{3 0} & \text { Rp7.500 }\end{array}$

\section{Gambar II}

Jika dilihat dalam contoh kasus pinjaman di atas, total bunga dalam satu bulan adalah Rp7,500.

2. Bunga menurun efektif (sliding rate)

Penghitungan bunga menurun efektif atau dikenal juga dengan nama sliding rate dilakukan pada setiap akhir periode cicilan. Dengan kata lain, bunga kredit akan dihitung dari saldo akhir Anda di setiap bulannya. Agar lebih jelas, berikut contoh sederhana penghitungan bunga menurun efektif.

Penghitungan Bunga Menurun Efektif

Saldo Akhir Pinjaman x (Suku Bunga Per Tahun/12)

$\begin{array}{lllll}\text { Bulan } & \text { Saldo Akhir } & \text { Angsuran } & \text { Angsuran } & \begin{array}{l}\text { Jumlah } \\ \text { Angsuran }\end{array} \\ & \text { Pinjaman } & \text { Pokok } & \text { Bunga/Bulan } & \begin{array}{l}\text { yang } \\ \text { Dibayarkan }\end{array} \\ 1 & \text { Rp5 juta } & \text { Rp1 juta } & \text { Rp50 ribu } & \text { Rp 1,050,000 } \\ 2 & \text { Rp4 juta } & \text { Rp1 juta } & \text { Rp40 ribu } & \text { Rp 1,040,000 } \\ 3 & \text { Rp3 juta } & \text { Rp1 juta } & \text { Rp30 ribu } & \text { Rp 1,030,000 } \\ 4 & \text { Rp2 juta } & \text { Rp1 juta } & \text { Rp20 ribu } & \text { Rp 1,020,000 } \\ 5 & \text { Rp1 juta } & \text { Rp1 juta } & \text { Rp10 ribu } & \text { Rp 1,010,000 } \\ \text { Total Dibayarkan } & \text { Rp5 juta } & \text { Rp150 ribu } & \text { Rp5, 150,000 }\end{array}$

\section{Gambar III}

Jadi, total angsuran bunga dalam enam bulan adalah Rp150 ribu. Meski penghitungan bunga menurun efektif terbilang lebih rumit dibandingkan dengan bunga menurun, namun cara ini dapat meringankan beban ketika melakukan pembayaran karena bunganya berkurang di setiap bulan.

3. Bunga anuitas (annuity rate)

Jika dilihat secara sekilas, bunga anuitas memiliki rumus penghitungan yang serupa dengan bunga menurun efektif. Perbedaannya ada pada persentase bunga yang dibayarkan tiap bulannya akan menurun, sementara nominal pokoknya meningkat. 
Jurnal Akuntansi \& Perpajakan, Volume 3, No. 1, Juli 2021

\section{Peran Koperasi Simpan Pinjam}

Karena berpedoman pada prinsip dasar koperasi, KSP Jasa Indah Makmur memiliki beberapa peran yang tujuannya untuk memperkuat ekonomi anggota, di antaranya:

1.Meningkatkan pendapatan sekaligus kesejahteraan anggota melalui penyaluran dana kredit.

2.Penetapan bunga ringan agar nasabah terhindar dari jeratan lintah darat.

3.Pembagian SHU sebagai suntikan dana segar bagi anggota yang berkontribusi aktif di koperasi simpan pinjam.

4.Pengelolaan dana simpanan atau tabungan anggota sebagai salah satu Bentuk Investasi.

5.Sebagai stimulus agar timbul hasrat untuk menyimpan atau menabung di koperasi.

\section{Keunggulan sistem akuntansi keuangan koperasi}

1. Lebih mudah di pahami dan juga di lihat bagi seluruh anggota koperasi. Begitu juga seandainya jika terjadi pergantian kepengurusan juga lebih mudah di lakukan. Pengurus yang lama hanya tinggal mengajarkan sedikit mengenai letak buku atau file yang di perlukan.

2. Semua file yang di perlukan dapat dengan mudah di temukan dan juga di pelajari. Semua ini juga di lakukan untuk menghindari kelupaaan terhadap berkas yang ada.

3. Menggunakan sistem akutansi juga sangat berguna untuk menghindari kesalahan dalam melakukan pembukuan mengenai keuntungan, modal dan juga hal lainnya yang di butuhkan.

4. Setelah mengetahui mengenai aktivitas kegiatan ini akan lebih mudah merencanakan dalam pengembangan usaha demi mensejahterakan anggotanya. Hal ini bisa di mulai dengan menambah banyaknya produk dan juga tempat yang akan di gunakan untuk tempat usaha. Dengan begitu maka keuntungan akan di tambah lagi.

5. Selain dapat menambah jumlah produk juga dapat memberikan jumlah variasi usaha yang ingin di jalankan. Variasi ini tentulah dapat di lakukan dengan kesepakatan seluruh anggota koperasi.

Contoh Laporan

Rekapitulasi Bulan Mei 2021 KSP Jasa Indah Makmur Kudus

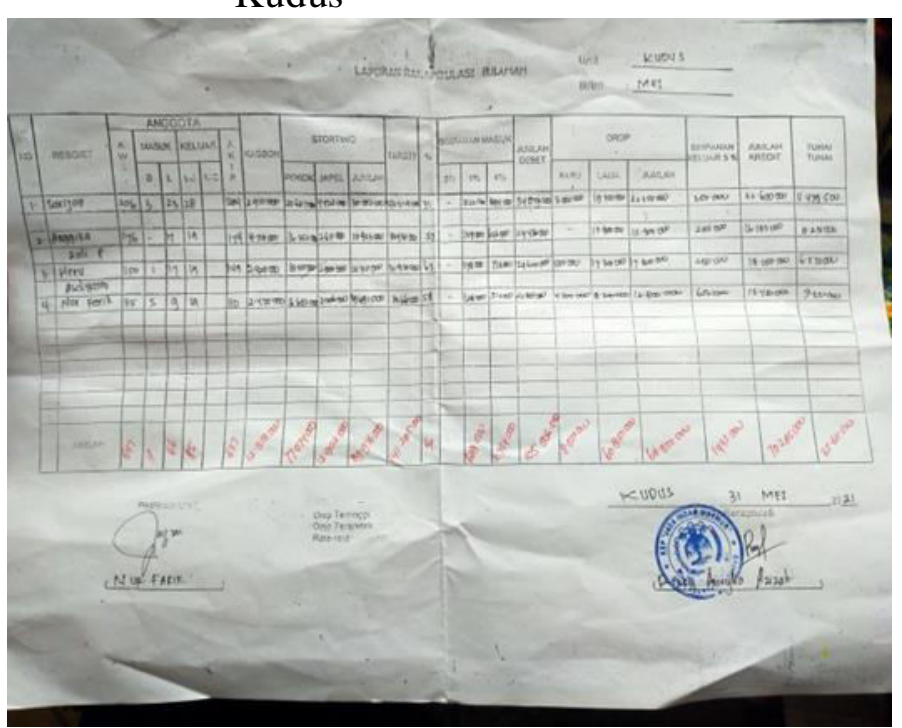

Gambar IV

\section{METODE PENELITIAN}

\section{Jenis Penelitian}

Metode pendekatan penelitian

yang digunakan dalam penelitian ini adalah metode kualitatif dan metode kuantitatif. Metode kualitatif yaitu penelitian yang menguraikan sifat-sifat dan keadaan sebenarnya dari suatu objek 
Jurnal Akuntansi \& Perpajakan, Volume 3, No. 1, Juli 2021

penelitian. Pengertian metode kualitatif adalah

metode yang digunakan untuk menggambarkan atau menganalisis suatu hasil penelitian tetapi tidak digunakan membuat kesimpulan yang lebih luas. Penelitian kuantitatif adalah penelitian ilmiah yang sistematis menggunakan angka terhadap bagian-bagian dan fenomena serta kausalitas hubungan-hubungannya. Tujuan penelitian kuantitatif adalah mengembangkan dan menggunakan model-model matematis, teoriteori dan/atau hipotesis.

\section{Teknik Pengumpulan Data}

Adapun teknik pengumpulan data yang dilakukan oleh penulis untuk menganalisis Laporan Rekapitulasi Bulanan pada Koperasi Jasa Indah Makmur dengan beberapa cara yaitu :

\section{Pengamatan (Observasi)}

Pengamatan (Observasi) Yaitu pengumpulan data yang dilakukan dengan mengamati secara langsung pada objek yang diteliti untuk memperoleh gambaran yang lebih jelas tentang permasalahan yang akan dibahas.

\section{Wawancara (Interview)}

Wawancara (Interview) Yaitu mengumpulkan informasi dengan media tanya jawab secara langsung dengan pimpinan Koperasi Jasa Indah Makmur Kudus.

3. Dokumentasi

Dokumentasi Yaitu teknik mengumpulkan,meneliti,mempelajari dokumen,catatan dan laporan- laporan yang berhubungan dengan masalah yang akan diteliti.

\section{Teknik Analisis Data}

Metode analisis data yang digunakan oleh penulis

1. Reduksi Data yakni merangkum, memilih hal-hal pokok yang dianggap penting. Memfokuskan pada hal-hal yang penting pada penelitian yang hanya Masa lah terkait pada sistem Laporan Rekapitulasi Bulanan KSP Jasa Indah Makmur.

2. Penyajian Data Adalah pengumpulan informasi yang terkait atas sistem Laporan Rekapitulasi Bulanan KSP Jasa Indah Makmur.

3. Verifikasi /Kesimpulan Adalah tahapan terakhir dalam proses analisis data.Pada bagian ini penulis mengutarakan kesimpulan dari data-data yang diperoleh, atas judul penelitian sistem Laporan Rekapitulasi Bulanan KSP Jasa Indah Makmur.

\section{HASIL DAN PEMBAHASAN}

Koperasi Jasa Indah Makmur adalah sebuah koperasi yang bergerak dibidang jasa. Koperasi ini beranggotakan sebanyak 20 orang. Dengan karyawan lapangan lakilaki 16 dan karyawan sebagai Admin 4 orang. Koperasi ini dibentuk pada tanggal 02 November 2004 dengan akta pendirian Nomor 1134.b/BH/IX/2-11-2004 yang beralamatkan di Jalan Mijen No. 100 RT. 04 RW.03 Kelurahan Mijen Kecamatan Kaliwungu Kabupaten Kudus.

\section{A. Sumber Daya Manusia}

Sumber daya manusia terhadap komponen sistem persediaan di Koperasi Jasa Indah Makmur Kudus masih terdapat kelemahannya meliputi:

1) Belum adanya karyawan yang ditugaskan khusus untuk menangani dan mengkontrol keadaan dilapangan.

2) Karyawan lapangan belum maksimal dalam mengelola keuangan.

3) Terjadinya perangkapan jabatan yaitu jabatan staff yang dilakukan okeh 1 orang. 
Jurnal Akuntansi \& Perpajakan, Volume 3, No. 1, Juli 2021

\section{B. Peralatan}

Peralatan yang dimiliki oleh pihak Koperasi Jasa Indah Makmur meliputi komputer yang digunakan untuk membuat pencatatan, pelaporan dan analisis mengenai keluar masuknya kas. Kalkulator yang digunakan dalam menghitung. Di asrama kantor juga ada peralatan Magic com untuk makan siang para karyawan. Berikut contoh nota pembelian Magic com

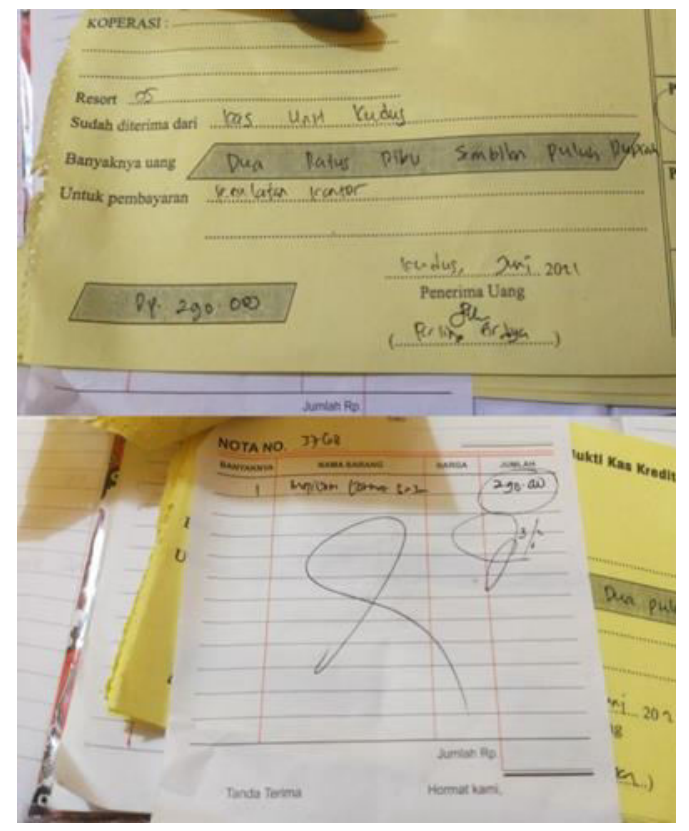

\section{Gambar V}

\section{C.Inventaris}

Karyawan lapangan yang berada di

KSP Jasa Indah Makmur Kudus mendapatkan 1 inventaris motor yang digunakan di lapangan. Inventaris motor yang ada di Kantor KSP Jasa Indah Makmur ada 16 motor sehingga setiap orang yang berada di lapangan di beri 1 inventaris motor yang harus dirawat. Mengenai servis dan perawatan motor dibiayai oleh kas yang ada dikantor KSP Jasa Indah Makmur. Berikut contoh nota servis yang diberikan karyawan lapangan

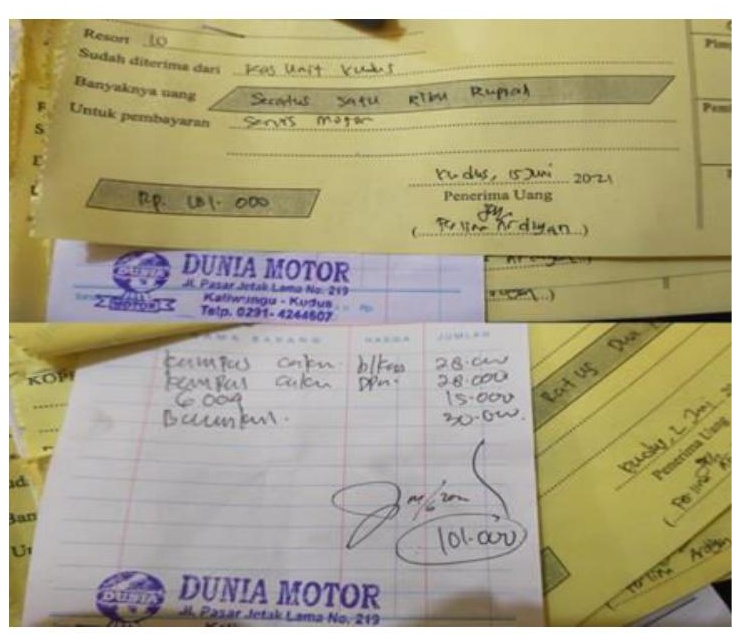

\section{Perlengkapan}

\section{Gambar VI}

Kantor KSP Jasa Indah Makmur menyediakan asrama untuk karyawan yang rumahnya berada diluar kota. Saat ini, karyawan yang ada di asrama 1 orang laki-laki yang merupakan karyawan lapangan. Perlengkapan yang ada di asrama meliputi magic com, televisi, kulkas, kipas angin. Berikut ini merupakan contoh nota pembelian perlengkapan asrama yang ada di KSP Jasa Indah Makmur Kudus

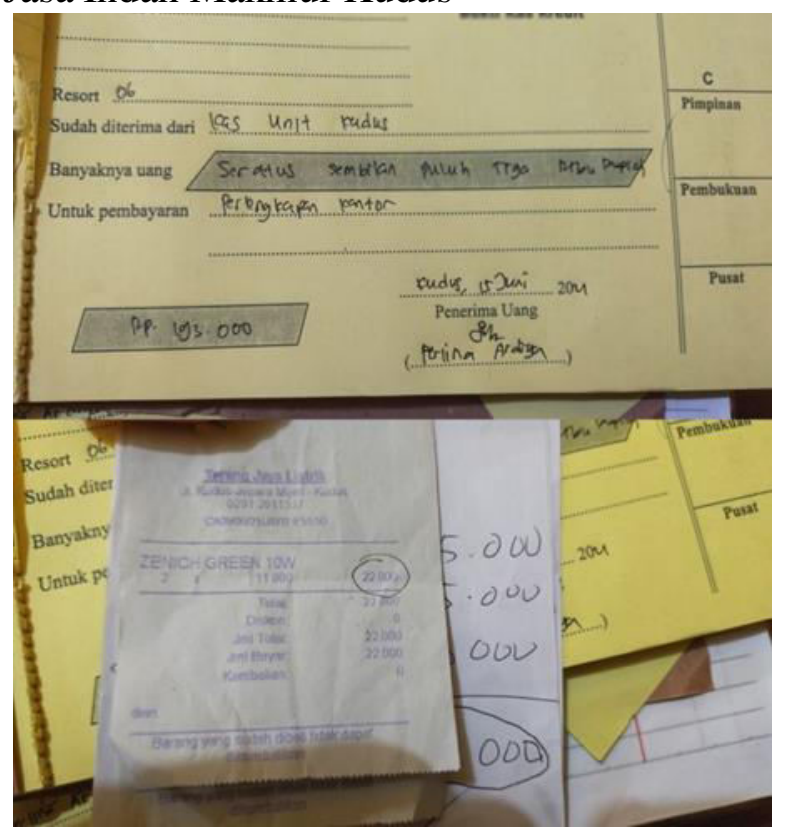

Gambar VII 
Jurnal Akuntansi \& Perpajakan, Volume 3, No. 1, Juli 2021

\section{KESIMPULAN}

Berdasarkan hasil penelitian dan pembahasan dibab sebelumnya, maka guna menjawab rumusan masalah dapat disimpulkan sebagai berikut :

Rekapitulasi di Koperasi Jasa Indah Makmur Kudus di buat setiap 1 bulan sekali yang dibuat oleh Karyawan Rekap KSP Jasa Indah Makmur Kudus. Besarnya persentase target disesuaikan target yang diluncurkan kantor pusat. Apabila persentase lebih dari 100\% maka, kondisi dilapangan masih stabil dan lebih membaik. Tetapi apabila persentase target kurang dari $100 \%$ maka kondisi lapangan memburuk dan pengeluaran kas semakin banyak daripada pemasukan anggota nasabah. Permasalahan pada Koperasi Jasa Indah Makmur ini terjadi pada Resort 4 yang memiliki Resort terendah dari yang lainnya karena Storting/Angsuran yang diangsur nasabah jumlah nya lebih sedikit dari Resort lainnya.

Ada banyak peraturan yang harus dipatuhi oleh nasabah koperasi simpan pinjam. Koperasi simpan pinjam saat ini mulai banyak digandrungi oleh masyarakat karena mampu untuk memberikan bantuan keungan dengan cepat dan langsung cair dalam beberapa menit. Tentunya hal tersebut juga akan membantu sekali dalam menstabilkan kondisi financial yang dimiliki saat ini agar bisa berjalan dengan lancar. Selanjutnya, nasabah koperasi simpan pinjam juga harus memiliki barang jaminan yang diberikan kepada pihak koperasi terkait dengan sejumlah uang yang nantinya akan bisa mereka dapatkan. Semakin besar jumlah jaminan yang nanti diberikan maka semakin besar pula jumlah uang yang akan bisa didapatkan oleh nasabah. Hal ini tentunya juga akan dapat memberikan manfaat bagi kesejahteraan banyak orang.

\section{SARAN}

Berdasarkan kesimpulan diatas sebagai masukan bagi Koperasi Jasa Indah Makmur Kudus, maka penulis mengajukan beberapa saran untuk membuat keputusan dalam mengurangi terjadinya kecurangan yang dapat dilakukan oleh karyawan sebagai berikut :

1. Struktur organisasi KSP Jasa Indah Makmur sebaiknya ada 2 staff yang ada supaya dapat bekerja sama dan cepat menyelesaikan tugas kerjanya sebagai staff.

2. Dalam sistem dan prosedur pencatatan akuntansi hendaknya Koperasi Jasa Indah Makmur sebaiknya menambahkan kekurangan dokumen yang belum lengkap mengenai persediaan 
Jurnal Akuntansi \& Perpajakan, Volume 3, No. 1, Juli 2021

barang bahwa memang sudah benar dan telah dilaksanakan.

3. Koperasi Jasa Indah Makmur sebaiknya melakukan perekrutan 2 orang atau 3 orang untuk bagian pengontrolan lapangan setiap harinya, karena disaat ini pimpinan yang selalu mengontrol setiap harinya.

\section{DAFTAR PUSTAKA}

Hongren, dkk, 2018, Akuntansi Di Indonesia, Salemba Empat, Jakarta

Jusup, Al Haryono, 2018, Dasar-Dasar Akuntansi, Bagian Penerbit STIE YKPN, Yogyakarta

Sari. 2018. Sistem Akuntansi (Pendekatan Manajemen). Yogyakarta: Liberty.

Soemarso, SR, 2018, Akuntansi Suatu Pengantar, Salemba Empat, Jakarta

Al Haryono Yusuf, 2018, Dasar-dasar Akuntansi, jilid 2 Cetakan Pertama, STIEYKPN, Yogyakarta.

Baridwan, Zaki, 2015, Sistem Akuntansi: Penyusunan Prosedur dan Metode, Badan Penerbitan Fakultas Ekonomi, Yogyakarta

Rumah Jurnal Online Fakultas Sains dan Teknologi Universitas Islam Negeri Sunan Ampel Surabaya, http://jurnalsaintek.uinsby.ac.id

Wayan Suwendra, S.E., M.Si 2017, Manajemen Koperasi, Cetakan pertama Universitas Gadjah Mada 